\title{
Comparative Analysis of Solar Powered Aquaponics and Hydroponics System
}

\author{
Rubeena tarranum*, Prasad S. kulkarni, U. Satish kumar, M. S. Ayyanagowdar, \\ Ramesh, G. S. Yedahalli and A. C. Sudhakar \\ Department of Soil and Water Engineering, College of Agricultural Engineering, University \\ of Agricultural Sciences, Raichur, Karnataka, India \\ *Corresponding author
}

\section{A B S T R A C T}

\begin{tabular}{|l|}
\hline Ke y w or d s \\
Aquaponics, \\
Hydroponics, \\
Lettuce, GIFT \\
\hline Article Info \\
\hline $\begin{array}{l}\text { Accepted: } \\
\text { 15 December } 2019 \\
\text { Available Online: } \\
\text { 20 January 2020 }\end{array}$ \\
\hline
\end{tabular}

Aquaponics is a combination of hydroponics (growing crops without soil) and traditional aquaculture. Nutrient from the fish waste feed the plants, and the plants filter the water to keep the fish healthy. An experiment was conducted to study and analyze the comparison between aquaponics, hydroponics for the cultivation of lettuce. GIFT was used as a source of nutrient as well as income generation in aquaponics where as in hydroponics nutrient solution was artificially prepared using various chemical combinations. The technique employed was deep water culture. Both the systems were designed and maintained properly. Fish pond was designed as $16 \mathrm{~m}^{3}$ with a bio-filter of $3 \mathrm{~m}^{3}$ capacity filled with sand and pebbles as filter media as a source of nutrient for aquaponics. 500L tank filled with nutrient solution was used as a source of nutrients for hydroponics. Volume of media was $0.57 \mathrm{~m}^{3}$. In order to improve the total returns of farmers the complete system was operated with solar energy and $120 \mathrm{~W}$ solar panel connected with DC pumps were used for water circulation. In the process of performance evaluation, mean Plant height, Plant width, No. of leaves, Root length, Root spread, Leaf area index, Chlorophyll content, fish weight, yield per plant, yield per pipe, yield per system and yield per hectare was found as 6.69 and $5.15(\mathrm{~cm}), 8.85$ and $4.36(\mathrm{~cm}), 3.64$ and $3.7($ no.s $), 4.27$ and $3.59(\mathrm{~cm}), 1.74$ and $0.87(\mathrm{~cm}) 0.80$ and $0.42,11.92$ and $9.3\left(\mu \mathrm{mol} / \mathrm{m}^{2}\right), 89.5(\mathrm{~g}), 62.88(\mathrm{~g}), 1194.64(\mathrm{~g}), 2.26(\mathrm{~kg})$ and $30.25(\mathrm{~kg})$ for aquaponics and hydroponics respectively.

\section{Introduction}

Open field based agriculture is facing some major challenges; most importantly decrease in percapital and availability. Due to rapid urbanization and industrialization as well as melting of icebergs are able land under cultivation is further going to decrease
(Sardare et al., 2013). Reducing agricultural water use while improving or maintaining economic and water productivity of the agricultural sector is a major challenge in arid and semiarid regions. To overcome this need the techniques like hydroponics and aquaponics are developed (Al-Karaki et al., 2012). 
Aquaponics is a food production system that combines aquaculture with hydroponics. Aquaponic systems use $10 \%$ or less of the water used in conventional soil based horticulture systems. These systems can be established in urban or harsh rural environments where land is very limited or of very poor quality.

Aquaponics is the symbiotic production of vegetables and fish. Fish eat food and release metabolites into the water derived from the food. These metabolites are further metabolized by bacteria and products of this metabolism are pumped into a plant growth bed where they are taken up by plants for nourishment (Ako, 2013).

Lettuce, herbs, and specialty greens (spinach, chives, basil, and water cress) have low to medium nutritional requirements and are well adapted to aquaponic systems (Diver, 2006). In aquaponics, nutrient-rich effluent from fish tanks is used to fertigate hydroponic production beds.

\section{Materials and Methods}

In Nursery preparation, grow trays were prepared for growing the lettuce. Watering was done after preparing the bed. Watering is carried out as per requirement, depending upon the climate and water holding capacity of soil.

Seeds of lettuce were sown in the growing trays filled with sterilized coco-peat. Chemical fertilizers like pseudomonas, Trico-derma and 19:19:19 were applied as per requirement.

Watering was done as per requirement on daily basis. Once the lettuce seedlings reached transplanting stage then the seedlings were shifted to both aquaponics and hydroponics systems. In aquaponics, assembly for aquaponics was prepared using Iron angular and PVC pipes. Numbers of holes of $5 \mathrm{~cm}$ diameter were drilled on the pipes for placing net pots. Net pots were filled with clay bolls as a media to support lettuce seedlings. Lettuce seedlings were transplanted to this system.

The only source of nutrients was the nutrient rich water coming from aquaculture system which was recirculated back to aquaculture system after nutrients take up by the plants.

Observations made were, Plant height $(\mathrm{cm})$, Plant width $(\mathrm{cm})$, No. of leaves (No.s), Root length $(\mathrm{cm})$, Root spread $(\mathrm{cm})$, Leaf area index, Chlorophyll content $\left(\mu \mathrm{mol} / \mathrm{m}^{2}\right)$, Yield per plant(g), Yield per pipe(g), Yield per system $(\mathrm{kg})$, Yield per hectare(T). Fish weight $(\mathrm{Kg})$ for $8,15,20$ and 30 days after transplanting.

In hydroponics, assembly for hydroponics was prepared using Iron angular and PVC pipes. Numbers of holes of $5 \mathrm{~cm}$ diameter were drilled on the pipes for placing net pots. Net pots were filled with clay bolls as a media to support lettuce seedlings.

Lettuce seedlings were transplanted to this system. The source of nutrients in this system was the combination of stock-A and stock-B solution prepared by mixing various chemical composition.

The used up nutrient solution from the hydroponics system was again re-circulated back to the nutrient tank. Observations made were, Plant height $(\mathrm{cm})$, Plant width $(\mathrm{cm})$, No. of leaves (No.s), Root length $(\mathrm{cm})$, Root spread $(\mathrm{cm})$, Leaf area index, Chlorophyll content $\left(\mu \mathrm{mol} / \mathrm{m}^{2}\right)$, Yield per plant $(\mathrm{g})$, Yield per pipe $(\mathrm{g})$, Yield per system(kg), Yield per hectare(T) for 8,15,20 and 30 days after transplanting. The obtained readings were compared using T-test at 5 per cent level of significance. 


\section{Results and Discussion}

In the process of a performance evaluation, Aquaponics mean Plant height was found as $6.69(\mathrm{~cm})$, Plant width was found as $8.85(\mathrm{~cm})$, No. of leaves was found as 3.64 (no.s), Root length was found as $4.27(\mathrm{~cm})$, Root spread was found as $1.74(\mathrm{~cm})$, Leaf area index was found as 0.80 , Chlorophyll content was found as $11.92\left(\mu \mathrm{mol} / \mathrm{m}^{2}\right)$.
Hydroponics mean Plant height was found as $5.15(\mathrm{~cm})$, Plant width was found as $4.36(\mathrm{~cm})$,No. of leaves was found as 3.70 (no.s), Root length was found as $3.59(\mathrm{~cm})$, Root spread was found as $0.87(\mathrm{~cm})$, Leaf area index was found as 0.42 , Chlorophyll content was found as $9.30\left(\mu \mathrm{mol} / \mathrm{m}^{2}\right)$.

Table.1 Design specifications of media

\begin{tabular}{|c|c|}
\hline \multicolumn{2}{|c|}{ Parameter and specifications } \\
\hline Parameters & Specifications \\
\hline Volume of each media & $0.0285 \mathrm{~m}^{3}$ \\
\hline volume of media & $0.5415 \mathrm{~m}^{3}$ \\
\hline Flow rate of the system & $2.76 \mathrm{~m}^{3} \mathrm{~h}^{-1}$ \\
\hline Diameter of outlet drain & $54 \mathrm{~mm}$ \\
\hline
\end{tabular}

Fig.1 A view of aquaponics system

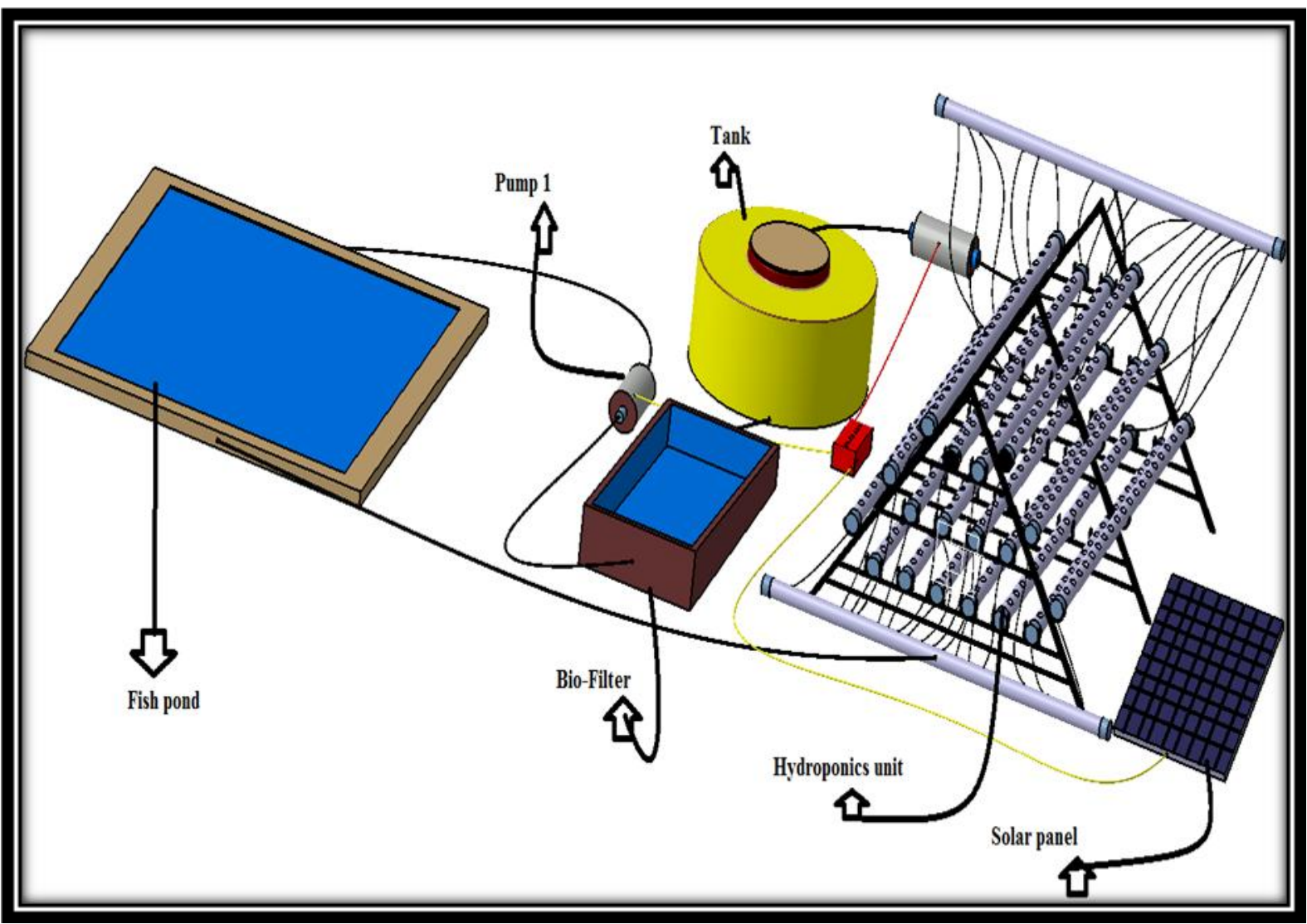


Table.2 Design specifications of Hydroponics system

\begin{tabular}{|c|c|c|c|}
\hline \multicolumn{4}{|c|}{ Hydroponics } \\
\hline Sl.no & Components & \multicolumn{2}{|c|}{ Dimensions/Specifications } \\
\hline \multirow[t]{9}{*}{1} & \multirow{9}{*}{ PVC pipes as grow media } & Length - & $3 \mathrm{~m}$ \\
\hline & & Diameter & $110 \mathrm{~mm}$ \\
\hline & & Guage & $4 \mathrm{~kg} \mathrm{~cm}^{-2}$ \\
\hline & & Number of holes in each pipe & 19 \\
\hline & & Number of pipes in a system & 19 \\
\hline & & Diameter of hole & $5 \mathrm{~cm}$ \\
\hline & & Spacing between holes & $10 \mathrm{~cm}$ \\
\hline & & Number of End caps & 38 \\
\hline & & Diameter of End caps & $110 \mathrm{~mm}$ \\
\hline \multirow[t]{4}{*}{2} & \multirow[t]{4}{*}{ Inlet PVC pipe } & Length & $1.77 \mathrm{~m}$ \\
\hline & & Diameter & $75 \mathrm{~mm}$ \\
\hline & & Number of End caps & 2 \\
\hline & & Diameter of End caps & $75 \mathrm{~mm}$ \\
\hline \multirow[t]{4}{*}{3} & \multirow[t]{4}{*}{ Outlet PVC pipe } & Length & $1.55 \mathrm{~m}$ \\
\hline & & Diameter & $75 \mathrm{~mm}$ \\
\hline & & Number of End caps & 2 \\
\hline & & Diameter of End caps & $75 \mathrm{~mm}$ \\
\hline \multirow[t]{2}{*}{4} & \multirow[t]{2}{*}{ Valves } & Diameter of valves & $16 \mathrm{~mm}$ \\
\hline & & Number of valves & 40 \\
\hline \multirow[t]{2}{*}{5} & \multirow[t]{2}{*}{ Net pots } & Diameter & $5 \mathrm{~cm}$ \\
\hline & & depth & $5 \mathrm{~cm}$ \\
\hline 6 & Clay bolls & Size & $8-15 \mathrm{~mm}$ \\
\hline 7 & Pipes & Size & $16 \mathrm{~mm}$ and $20 \mathrm{~mm}$ \\
\hline
\end{tabular}

Table.3 Design specifications of aquaculture system

\begin{tabular}{|c|c|c|}
\hline \multirow{4}{*}{ Sl.no } & Components & Aquaculture \\
\hline 1 & Farm pond & Dimensions/Specifications \\
\cline { 3 - 3 } & & Length $-4 \mathrm{~m}$ \\
\cline { 2 - 3 } & & Width $-4 \mathrm{~m}$ \\
\cline { 2 - 3 } & Depth $-1 \mathrm{~m}$ \\
\hline 2 & Lining material & Volume $=16 \mathrm{~m}^{3}$ \\
\hline 3 & Aerator & Black polyethene lining material \\
\hline & & Current $=10 \mathrm{~A}$ \\
\hline & & Voltage $=16.5 \mathrm{~V}$ \\
\hline
\end{tabular}


Table.4 Design specifications of Bio-filter

\begin{tabular}{|c|c|c|}
\hline \multicolumn{2}{|c|}{ Bio-Filter } \\
\hline Sl.no & Components & Dimensions/Specifications \\
\hline 1 & Filter & Length $-4 \mathrm{~m}$ \\
\cline { 3 - 3 } & & Width $-1.5 \mathrm{~m}$ \\
\cline { 2 - 3 } & & Depth $-0.5 \mathrm{~m}$ \\
\hline 2 & Lining material & Volume $=3 \mathrm{~m}^{3}$ \\
\hline 3 & Filter media & Black polyethene lining material \\
\hline
\end{tabular}

Fig.2 A view of hydroponics system

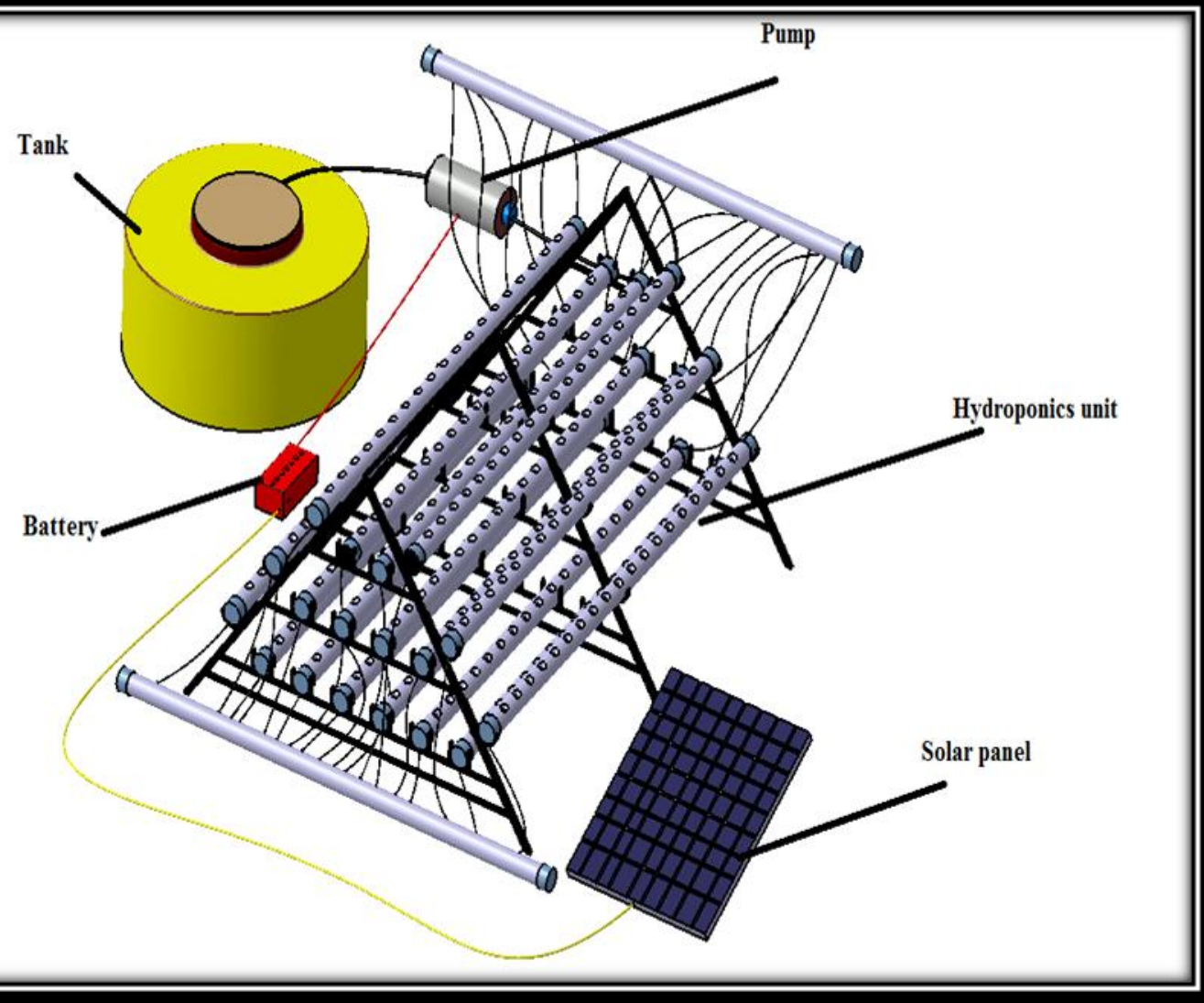


Fig.3 Yield per hectare of the system

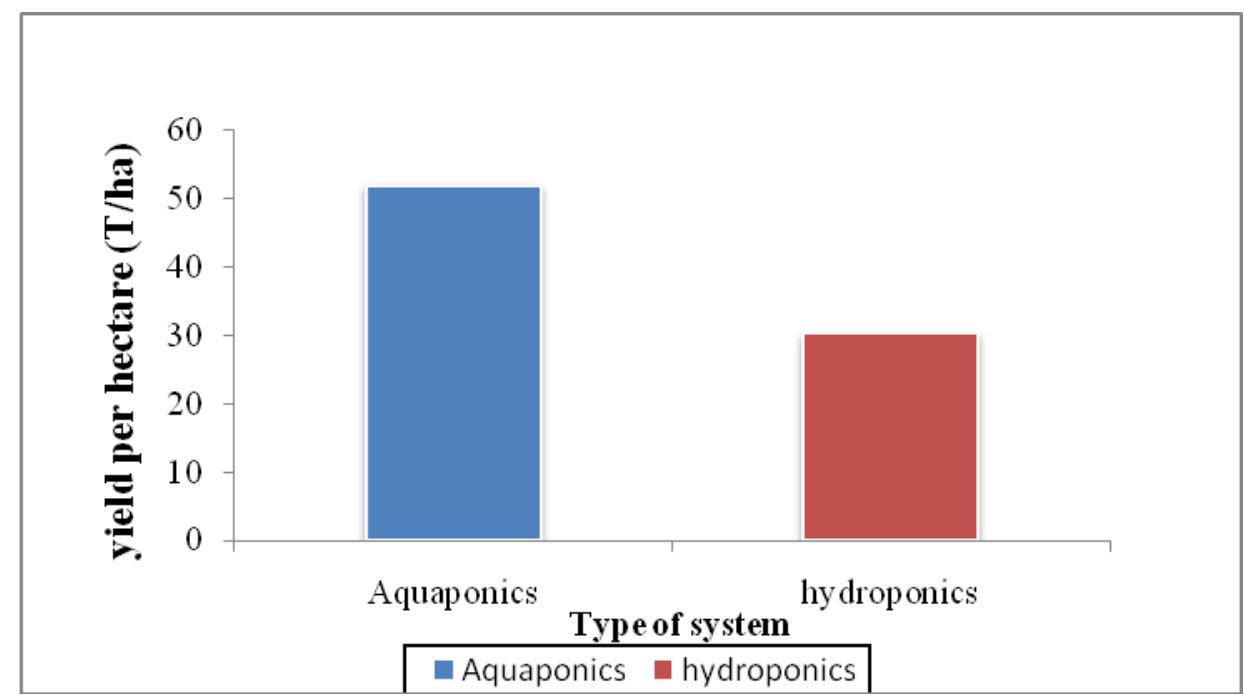

Fig.4 Comparison of aquaponics and hydroponics plants

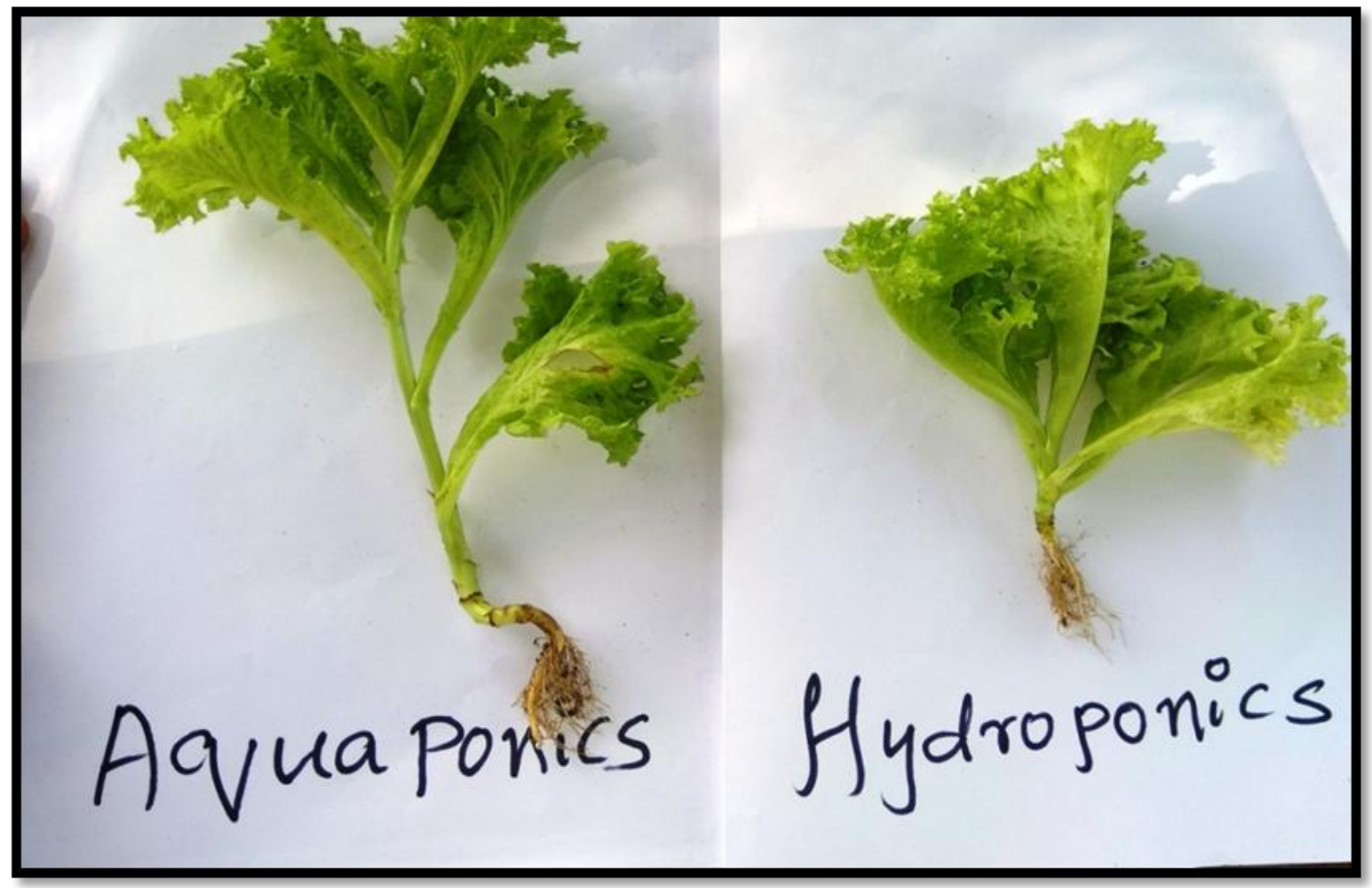


Table.5 Performance evaluation of both systems

\begin{tabular}{|c|c|c|c|}
\hline Sl. No & Parameter & Aquaponics & Hydroponics \\
\hline $\mathbf{1}$ & Mean plant height $(\mathrm{cm})$ & 6.69 & 5.15 \\
\hline $\mathbf{2}$ & Mean plant width $(\mathrm{cm})$ & 8.85 & 4.36 \\
\hline $\mathbf{3}$ & Mean No. of leaves $(\mathrm{cm})$ & 3.64 & 3.7 \\
\hline $\mathbf{4}$ & Mean root length $(\mathrm{cm})$ & 4.27 & 3.59 \\
\hline $\mathbf{5}$ & Mean root spread $(\mathrm{cm})$ & 1.74 & 0.87 \\
\hline $\mathbf{6}$ & Chrolophyll content $\mu \mathrm{mol} / \mathrm{m} 2$ & 11.92 & 9.3 \\
\hline $\mathbf{7}$ & Leaf area index & 0.8 & 0.42 \\
\hline $\mathbf{8}$ & Yield per plant $(\mathrm{g})$ & 108.18 & 62.88 \\
\hline $\mathbf{9}$ & Yield per pipe $(\mathrm{g})$ & 2055.44 & 1194.64 \\
\hline $\mathbf{1 0}$ & yield per system $(\mathrm{kg})$ & 3.9 & 2.26 \\
\hline $\mathbf{1 1}$ & Yield per hectare $\left(\mathrm{T} \mathrm{ha}{ }^{-1}\right)$ & 52 & 30.25 \\
\hline
\end{tabular}

production is seen from aquaponics

Yield per plant, Yield per pipe and Yield per production when compared with hydroponics. system was found to be 108.18 and $62.88 \mathrm{~g}$, 2055.44 and $1194.64 \mathrm{~g}, 3.90$ and $2.26 \mathrm{~kg}$ for aquaponics and hydroponics respectively and yield per hectare was found to be 52 and 30.25 T/ha for aquaponics and hydroponics respectively.

From the study it can be concluded that aquaponics system is very efficient in terms of water, nutrient as well as energy. This technique will be well adopted and much efficient when the micro-climatic conditions are under control.Two agricultural products (fish and vegetables) are produced from one nitrogen source (fish food), Hence if farmers implement this technique there will be much financial security as there are two source for finance generation. This technique is extremely water-efficient soil-less culture, do not require additional fertilizers or chemical pesticides. Higher yields and qualitative

In hydroponics the only source of income generation is crop, whereas in aquaponics a farmer can get two sources of income i,e Crop and Fish with same amount of water.

\section{References}

Ako, H. 2013. How to build and operate a simple small-to-large scale aquaponics system. $J$. World Aquaculture Soc., 6(3): 20-32.

Al-Karaki, G. and Al-Hashimi, M. 2012. Green fodder production and water use efficiency of some for age crops under hydroponic conditions. Int. Scholarly Res. Network, 12(12): $1-5$.

Diver, S. 2006. In-Aquaponics Integration of hydroponics with aquaculture. National Sustainable Agriculture Information Service, United States, 1-28.

Sardare, M. and Admane, S. 2013. A review on plant without soil-hydroponics. Int. J. Res. Engi. Technol., 02(03): 299-304.

\section{How to cite this article:}

Rubeena tarranum, Prasad S. kulkarni, U. Satish kumar, M. S. Ayyanagowdar, Ramesh, G. S. Yedahalli and Sudhakar, A. C. 2020. Comparative Analysis of Solar Powered Aquaponics and Hydroponics System. Int.J.Curr.Microbiol.App.Sci. 9(01): 2656-2662.

doi: https://doi.org/10.20546/ijcmas.2020.901.301 